\title{
PENGARUH TENURE CEO TERHADAP KETERBACAAN NARASI PENGUNGKAPAN
}

\author{
Moh. Baqir Ainun* \\ Mahasiswa Magister Akuntansi, Universitas Airlangga, Indonesia
}

\begin{abstract}
This study examines the influence of CEO tenure on readability of narratives disclosure. This study also included company size and company age as control variables. The sample used in this study was 482 companies listed on the Indonesia Stock Exchange in 2018. There are not many studies on readability of narratives disclosure in Indonesia, so this study is expected to motivate academics to develop studies on disclosure narrative readability. The results showed that more longer CEO tenure could increase the readability of narratives disclosure. This condition can occur because CEO with longer tenure will be better able to communicate firm conditions in naratives disclosure that is simpler and easier to understand than CEO with shorter tenure. Moreover, firm size and firm age add complexity to narratives disclosure and decrease readability. This condition occurs because more larger the firm size and more older the firm age can create more items that must be disclosed in the narratives disclosure. This study can use to enrich the literature about influence of CEO tenure on readability of narratives disclosure.
\end{abstract}

JEL : G30, G41, M12.

Keywords : tenure, readability, disclosure, upper echelons theory.

\begin{abstract}
ABSTRAK
Penelitian ini bertujuan untuk menguji pengaruh tenure CEO terhadap keterbacaan narasi pengungkapan. Penelitian ini juga menyertakan ukuran perusahaan dan umur perusahaan sebagai variabel kontrol. Sampel yang digunakan dalam penelitian ini adalah 482 perusahaan yang terdaftar di Bursa Efek Indonesia pada tahun 2018. Penelitian tentang keterbacaan narasi pengungkapan belum banyak dilakukan di Indonesia, sehingga penelitian ini diharapkan dapat memotivasi akademisi untuk mengembangkan studi tentang keterbacaan narasi pengungkapan. Hasil penelitian ini menunjukkan bahwa tenure CEO yang lebih lama dapat meningkatkan keterbacaan narasi pengungkapan. Hal ini terjadi karena CEO dengan tenure yang lama lebih mampu untuk mengkomunikasikan kondisi perusahaan yang komplek dengan bahasa yang lebih sederhana dan lebih mudah dibaca dari pada CEO dengan tenure yang lebih pendek. Selain itu, ukuran perusahaan dan umur perusahaan menambah kompleksitas narasi pengungkapan dan mengurangi keterbacaan. Hal ini dikarenakan semakin besar ukuran perusahaan dan semakin tua perusahaan dapat menyebabkan semakin kompleksnya narasi pengungkapan yang dihasilkan. Hasil penelitian ini dapat memperkaya literatur tentang pengaruh tenure CEO terhadap keterbacaan narasi pengungkapan.
\end{abstract}

Kata Kunci : tenure, keterbacaan, pengungkapan, teori upper echelons.

\section{PENDAHULUAN}

Laporan tahunan merupakan alat komunikasi yang digunakan manajemen untuk menyampaikan informasi terkait dengan kinerja perusahaan selama satu tahun berjalan (Guthrie et al., 2004; Morsing dan Schultz, 2006), sehingga kejelasan laporan tahunan menjadi hal yang penting untuk memastikan bahwa masyarakat dapat memahami informasi tersebut dengan baik

\footnotetext{
*Email : moh.baqir.ainun-2018@feb.unair.ac.id

Received : 17-10-2019, Accepted : 26-12-2019, Published : 28-04-2020.

P-ISSN : 2087-9954, E-ISSN : 2550-0066. DOI : http://dx.doi.org/10.26418/jebik.v9i1.37114
} 
(Xu et al., 2018). Unsur kualitatif dari laporan tahunan berupa narasi pengungkapan yang disediakan oleh organisasi merupakan salah satu unsur yang manarik bagi banyak peneliti (Guthrie et al., 2004). Narasi pengungkapan dalam laporan tahunan perusahaan memiliki daya tarik tersendiri bagi para peneliti dan pembuat kebijakan akuntansi dan telah menjadi fokus perhatian investor, regulator dan masyarakat luas terkait dengan tingkat keterbacaan yang dihasilkan (Leung et al., 2015).

Penelitian-penelitian terdahulu telah banyak memberikan bukti bahwa keterbacaan dari narasi pengungkapan dalam laporan tahunan berhubungan dengan kinerja perusahaan (de Souza et al., 2019; Hassan et al., 2019; Li, 2008; Smith et al., 2006), reaksi investor (Rennekamp, 2012), biaya agensi (Luo et al., 2018), prediksi kebangkrutan (Mai et al., 2019), manajemen laba (Lo et al., 2017), dan pengembalian saham di masa depan (Wisniewski dan Yekini, 2015).

Adanya efek signifikan yang ditimbulkan oleh tingkat keterbacaan yang dihasilkan dapat menjadi alasan kuat untuk menyelidiki faktor-faktor yang dapat mempengaruhi keterbacaan itu sendiri. Hasan (2018) menyatakan bahwa kemampuan manajerial merupakan salah satu faktor yang dapat mempengaruhi tingkat keterbacaan. Selain itu, Xu et al. (2018) juga menemukan bukti bahwa umur CEO yang lebih tua dapat menciptakan narasi pengungkapan dengan tingkat keterbacaan yang lebih tinggi. Namun demikian, penelitian-penelitian yang mengevaluasi faktor karakteristik dari manajer untuk menciptakan tingkat keterbacaan yang beragam masih jarang dilakukan.

Narasi pengungkapan harus ada dalam laporan tahunan emiten di Indonesia sesuai dengan Keputusan Ketua Badan Pengawas Pasar Modal dan Lembaga Keuangan Nomor: Kep431/B1/2012 dimana pihak yang bertanggung jawab untuk menyusun laporan tahunan tersebut adalah Direksi sesuai dengan Peraturan Otoritas Jasa Keuangan Nomor 29/POJK.04/2016. Penelitian ini mencoba untuk menyertakan faktor karakteristik individu dari pihak yang bertanggung jawab untuk menyusun narasi pengungkapan kedalam analisis tentang tingkat keterbacaan dari narasi pengungkapan.

Teori upper echelons menyatakan bahwa karakteristik pimpinan dalam sebuah organisasi dapat memprediksi hasil dari organisasi tersebut, baik dalam bentuk pilihan strategis maupun tingkat kinerja (Hambrick dan Mason, 1984). Selanjutnya, Hambrick (2007) menyatakan bahwa karakteristik demografis eksekutif seperti umur, pengalaman, pendidikan, dan gender dapat digunakan sebagai proxy yang valid untuk mengetahui bagaimana eksekutif dapat mempengaruhi strategi, arah, dan operasi perusahaan. Oleh karena itu, karakteristik demografis dari CEO diharapkan akan manjadi penentu tingkat keterbacaan yang dihasilkan.

Penelitian $\mathrm{Xu}$ et al. (2018) memberikan bukti yang terbatas pada umur CEO berhubungan positif dengan keterbacaan narasi pengungkapan, padahal pengalaman yang dimiliki oleh CEO juga merupakan karakteristik yang perlu diperhatikan. Penelitian ini berfokus pada bagaimana pengalaman yang dimiliki oleh CEO dapat mempengaruhi tingkat keterbacaan dari narasi pengungkapan yang disusunnya.

Pengalaman yang dimaksud dalam penelitian ini merupakan tenure CEO pada perusahaan. Penggunaan tenure lebih spesifik dari pada pengalaman yang diidentikkan dengan bertambahnya umur seperti yang disampaikan Xu et al. (2018). Tenure akan menggambarkan pengalaman dari CEO yang berfokus pada tempat dia memimpin perusahaan saat ini, sehingga pengalaman menjadi CEO di perusahaan lain sebelumnya tidak diperhatikan dalam penelitian. 
Hal ini relevan karena karakteristik dari setiap perusahaan adalah heterogen, sehingga ketika CEO baru menjabat di sebuah perusahaan, dia harus beradaptasi dan memahami karakteristik perusahaan yang kemungkinan besar berbeda dari karakteristik perusahaan sebelumnya yang dia pimpin.

Katmon et al. (2017) menyatakan bahwa semakin panjang tenure yang dimiliki oleh CEO akan seiring dengan meningkatnya pemahaman pada kondisi perusahaan, peraturan, dan regulasi. Pada akhirnya, tenure CEO akan meningkatkan kualitas pengungkapan (Donoher et al., 2007), dimana kualitas pengungkapan akan meningkat seiring dengan meningkatnya tingkat keterbacaan (Luo et al., 2018).

Pada akhirnya, hasil penelitian ini diharapkan dapat memberikan tambahan literatur terkait dengan pengaruh tenure CEO terhadap keterbacaan narasi pengungkapan. Penelitian ini diharapkan dapat menjadi acuan bagi pihak yang bertanggung jawab untuk mengevaluasi kinerja CEO agar mempertimbangkan karakteristik CEO khususnya tenure CEO, merujuk tentang bagaimana tenure CEO dapat menjelaskan masalah raedability dari sudut pandang ontologis dan oportunistik. Selain itu, penelitian ini diharapkan dapat memotivasi para akademisi untuk mengembangkan penelitian tentang keterbacaan narasi pengungkapan yang masih belum banyak diteliti di Indonesia, padahal keterbacaan narasi pengungkapan merupakan aspek penting karena erat kaitannya dengan apakah informasi yang terkandung dalam narasi pengungkapan dapat dipahami oleh pengguna.

\section{KAJIAN LITERATUR}

\subsection{Teori Upper Echelons}

Teori upper echelons merupakan teori yang dikembangkan oleh Hambrick dan Mason (1984). Teori ini menjelaskan bahwa karakteristik pimpinan dalam sebuah organisasi dapat memprediksi pilihan strategis maupun tingkat kinerja organisasi. Teori upper echelons menyatakan bahwa untuk mengetahui alasan keputusan yang diambil oleh sebuah organisasi maka hal yang harus dipertimbangkan adalah bias atau disposisi dari eksekutif sebagai pihak yang paling berkuasa dalam organisasi tersebut. Interpretasi yang dilakukan oleh eksekutif akan dipengaruhi oleh pengalaman, nilai, dan kepribadiannya. Interpretasi ini kemudian akan berpengaruh terhadap pilihan strategi yang akan ditentukan (Hambrick dan Mason, 1984).

Hambrick (2007) menyatakan bahwa teori upper echelons memiliki dua bagian yang saling berhubungan. Pertama, tindakan eksekutif yang didasari atas interpretasi pribadi. Kedua, pengalaman, nilai, dan kepribadian dari eksekutif akan menjadi penentu dari interpretasi tersebut. Teori ini menyatakan bahwa karakteristik demografis eksekutif seperti umur, pengalaman, pendidikan, dan gender dapat digunakan sebagai proxy yang valid.

Teori upper echelons juga memperkenalkan dua pemoderasi pada hubungan karakteristik eksekutif dengan pilihan strategi yang dipilih sebagai berikut, (1). Manajer discretion (wewenang manajer); wewenang menajer merupakan variabel yang dianggap dapat menginteraksi hubungan antara karakteristik eksekutif dengan pilihan strategi. Hambrick (2007) menyatakan bahwa wewenang berasal dari kondisi lingkungan, faktor organisasi, dan dari eksekutif itu sendiri. Jika eksekutif memiliki wewenang yang besar, maka karakteristik eksekutif akan tercermin dalam strategi dan kinerja. Namun, jika wewenang yang dimiliki kecil, maka karakteristik eksekutif akan menjadi sesuatu yang kurang penting. (2). Executive job demands; 
Hambrick (2007) menyatakan bahwa eksekutif yang berada di bawah tuntutan pekerjaan yang berat akan lebih mengandalkan karakteristik demografinya dalam proses pengambilan keputusan, sehingga proses pengambilan keputusan akan lebih condong pada subjektifitas dari eksekutif itu sendiri. Sedangkan eksekutif yang menghadapi tuntutan yang lebih ringan akan lebih mampu mempertimbangkan pengambilan keputusan berdasarkan kondisi yang objektif.

Pada dasarnya, teori upper echelons menghubungkan antara karakteristik eksekutif dengan pilihan yang diambil disesuaikan dengan situasi yang dihadapi. Namun Hambrick (2007) menegaskan bahwa pengambilan keputusan yang dilakukan bisa didasarkan pada keinginan mereka sendiri atau karena adanya tuntutan dari dewan.

Teori upper echelons dapat mencerminkan nilai-nilai, pengalaman, dan kepribadian aktor yang kuat dalam suatu organisasi (Wei et al., 2018). Pimpinan atau aktor terkuat dalam perusahaan adalah CEO, sehingga karakteristik dari CEO dapat menjadi tolak ukur pilihan strategi dan kinerja dari perusahaan tersebut.

\subsection{Keterbacaan (Readability)}

Readability (keterbaacaan) merupakan istilah yang pada umumnya digunakan oleh peneliti-peneliti yang mengevaluasi tingkat keterbacaan dari sebuah narasi pengungkapan. Keterbacaan merupakan sebuah elemen yang berhubungan erat dengan teks tertulis yang didefinisikan sebagai komunikasi efektif untuk mengukur relevansi dari sebuah informasi (de Souza et al., 2019). Keterbacaan juga berkaitan dengan bagaimana investor individu dan analis mampu untuk mengolah financial disclosure menjadi sebuah informasi yang relevan untuk pengambilan keputusan (Loughran dan McDonald, 2014).

Keterbacaan akan mempertimbangkan kompleksitas dari sebuah teks, jumlah kata, ukuran file, dan jumlah halaman (Bonsall IV et al., 2017; de Souza et al., 2019; Ginesti et al., 2018). Dalam ilmu akuntansi, keterbacaan diukur melalui tingkat kesulitan dari sebuah teks dan bagaimana teks tersebut dapat dipahami dengan baik. Tolak ukur keterbacaan merupakan kondisi dimana informasi yang disampaikan diterima dengan mudah (de Souza et al., 2019). Namun, keterbacaan bukanlah sebuah konsep sempit yang hanya dapat diartikan dengan kompleksitas sebuah kata. Lebih dari itu, ukuran keterbacaan dalam aplikasi tertentu sangat tergantung pada bagaimana konsep itu didefinisikan (Loughran dan McDonald, 2014).

Xu et al. (2018) menyatakan bahwa kompleksitas dari narasi pengungkapan dapat ditimbulkan oleh dua faktor. Pertama, penjelasan ontologis yang menyatakan kompleksitas narasi pengungkapan akan meningkat seiring dengan kompleksitas operasi yang dimiliki perusahaan. Kedua, penjelasan oportunistik yang menyatakan kompleksitas narasi pengungkapan akan dengan sengaja ditingkatkan sebagai upaya eksekutif untuk mengaburkan dan membingungkan pembaca.

Kondisi pertama menyatakan bahwa keterbacaan dari narasi pengungkapan dapat menurun dan menyebabkan pembaca lebih sulit untuk memahami informasi karena kondisi perusahaan yang memang menuntut manajemen untuk mendeskripsikan narasi pengungkapan dengan panjang lebar misalnya karena besarnya aset yang dimiliki. Hal ini dapat dilihat dari penelitian-penelitian terdahulu yang selalu menyertakan ukuran perusahaan dalam analisisnya (seperti Li, 2008; Xu et. al., 2018; de Souza et al., 2019) dengan argumen bahwa semakin besar 
perusahaan maka manajer akan membutuhkan penjelasan yang semakin komplek terkait dengan aset yang dimiliki sehingga keterbacaan dari narasi pengungkapan akan semakin rendah.

Kondisi kedua menyatakan bahwa keterbacaan dapat menjadi salah satu strategi yang dapat digunakan pihak manajemen untuk memperoleh feedback yang diinginkan (Asay et al., 2018). Keterbacaan narasi pengungkapan pada perusahaan dalam kondisi baik akan lebih tinggi dari pada perusahaan dalam kondisi tidak baik. Narasi yang digunakan oleh perusahaan dalam kondisi baik akan cenderung lebih simpel dan jelas, sedangkan perusahaan dalam kondisi buruk cenderung lebih kompleks dan dianggap sebagai upaya mengaburkan berita buruk tersebut (de Souza et al., 2019; Li, 2008; Smith et al., 2006). Kondisi oportunistik manajemen untuk mengaburkan berita buruk disebut sebagai obfuscation hypothesis. Sederhananya, obfuscation hypothesis merupakan kondisi dimana manajer dengan sengaja meningkatkan kompleksitas narasi pengungkapan sebagai upaya untuk mengaburkan berita buruk dari perhatian pembaca.

\subsection{Pengungkapan (Disclosure)}

Wolk et al. (2013) mendefinisikan pengungkapan sebagai berikut:

"Disclosure is concerned with information in both the financial statements and supplementary communications' including footnotes, post-statement events, management's discussion and analysis of operations for the forthcoming year, financial and operating forecasts, the summary of significant accounting policies, and additional financial statements covering segmental disclosure and extensions beyond historical costs."

Dari definisi ini, pengungkapan merupakan sarana penyedia informasi yang tidak dapat diperoleh dari statemen keuangan formal.

Securities and Exchange Commission (SEC) menafsirkan pengungkapan menjadi dua aspek (Wolk et al., 2013). Pertama, protective disclosure merupakan tujuan pengungkapan yang timbul dari adanya asumsi bahwa tidak semua pengguna laporan keuangan mampu untuk mendapatkan, mengolah, dan menangkap substansi informasi ekonomis dari pos statement keuangan, sehingga pengungkapan diharapkan dapat menjadi pelindung investor dari penyajian keuangan yang unfair. Kedua, informative disclosure merupakan tujuan pengungkapan yang lahir dari asumsi bahwa pengguna laporan keuangan memiliki keterbatasan dalam memperoleh dan mengolah informasi, sehinga pengungkapan dapat menjadi sarana dalam menyediakan informasi untuk mengefektifkan pengambilan keputusan pengguna.

Aspek kedua dari penafsiran yang disampaikan SEC lebih menekankan pada bagaimana pengungkapan dapat menyajikan informasi untuk mendukung pengambilan keputusan yang efektif, sehingga narasi yang disampaikan dalam pengungkapan harus jelas dan tidak membingungkan pembaca. Narasi pengungkapan yang dibuat kompleks oleh manajer dapat membuat pambaca kesulitan untuk memahami informasi apa yang sebenarnya disampaikan (de Souza et al., 2019), sehingga alih-alih membantu pengguna dalam pengambilan keputusan yang efektif justru membingungkan pengguna karena kompleksitas narasi pengungkapan yang berlebihan.

\subsection{Tenure CEO terhadap Keterbacaan Narasi Pengungkapan}

Tenure CEO menunjukkan berapa lama CEO memegang kendali sebuah perusahaan. Tenure CEO merupakan faktor yang telah disoroti oleh banyak penelitian khususnya dalam penelitian akuntansi manajemen terkait dengan pengalaman untuk meningkatkan kinerja 
perusahaan. CEO yang memiliki tenure panjang akan menambah pengetahuanya tentang lingkungan perusahaan baik lingkungan internal perusahaan maupun eksternal perusahaan (Kuppens, 2012).

Katmon et al. (2017) menyatakan bahwa lama tenure yang dimiliki oleh CEO akan seiring dengan meningkatnya pemahaman CEO pada kondisi perusahaan, peraturan, dan regulasi. Pada akhirnya, tenure CEO akan meningkatkan kualitas pengungkapan (Donoher et al., 2007), dimana kualitas pengungkapan akan meningkat seiring dengan meningkatnya tingkat keterbacaan (Luo et al., 2018).

CEO yang memiliki tenure panjang diasumsikan akan memiliki pengalaman dan pengetahuan yang lebih tentang cara terbaik dalam mengkomunikasikan kondisi perusahaan kepada publik. Hal ini menunjukkan bagaimana tenure CEO dapat menjelaskan penjelasan ontologis dari masalah keterbacaan. CEO yang memiliki tenure yang panjang akan lebih memahami bagaimana cara menyampaikan informasi yang lebih mudah untuk dipahami dalam kondisi perusahaan yang kompleks misalnya karena besarnya aset yang dimiliki atau karena tuanya umur perusahaan yang dipimpin (Xu et al., 2018).

Selain itu, bertambahnya tenure CEO akan seiring dengan bertambahnya loyalitas CEO pada perusahaan, sehingga CEO akan memberikan kinerja terbaiknya dan menghindari perbuatan-perbuatan oportunistik diluar kepentingan perusahaan (Streers dan Porter, 1983). Hal ini menunjukkan bagaimana tenure CEO menjelaskan penjelasan oportunis dari masalah keterbacaan. Dalam kondisi buruk, CEO berkesempatan untuk melakukan perbuatan oportunsitik untuk mengaburkan kondisi buruk tersebut kepada investor dengan harapan berita buruk yang terjadi tidak terlalu memberikan dampak negatif bagi perusahaan. Pengaburan informasi buruk dilakukan manajemen sebagai salah satu upaya agar posisi dan insentifnya tetap aman. CEO yang memiliki tenure yang panjang akan menumbuhkan loyalitas yang tinggi bagi perusahaan, sehingga setiap keputusan dan tindakan yang dilakukan akan berlandaskan pada kepentingan perusahaan dan bukan untuk kepentingan pribadi. Pada akhirnya, tenure CEO yang lama akan mencegah CEO untuk mengaburkan informasi yang sebenarnya pada narasi dsiclosure (de Souza et al., 2019); Asay et al., 2018).

Berdasarkan pemaparan diatas maka penulis menduga bahwa bertambahnya tenure CEO akan dapat meningkatkan keterbacaan narasi pengungkapan yang disusun oleh CEO tesebut, sehingga hipotesis yang diajukan dalam penelitian ini adalah sebagai berikut Tenure CEO berpengaruh positif siginifikan terhadap keterbacaan narasi pengungkapan.

Penelitian ini juga menyertakan dua variabel kontrol sebagai upaya untuk menghilangkan bias hasil penelitian. Peneliti menyertakan ukuran perusahaan dan umur perusahaan dalam model sebagai variabel kontrol. Ukuran perusahaan yang besar cenderung mengungkapkan lebih banyak butir-butir laporan keuangan karena banyaknya informasi yang yang harus diungkapkan (Heniwati dan Yani, 2011). Li (2008) menyatakan bahwa bertambahnya ukuran perusahaan akan mendorong perusahaan untuk menjabarkan narasi pengungkapan dengan lebih komplek sehingga semakin besar ukuran perusahaan maka semakin kompleks narasi pengungkapan yang dibuat dan pada akhirnya menurunkan tingakat keterbacaannya. Lebih lanjut, Li (2008) menyatakan bahwa perusahaan yang lebih tua kemungkinan menunjukkan perbedaan keterbacaan laporan tahunan karena berkurangnya asimetri informasi dan berkurangnya ketidakpastiaan informasi pada perusahaan. Jika investor lebih familiar dengan 
perusahaan, perusahaan akan menyajikan laporan tahunan yang lebih simpel dan pada akhirnya akan meningkatkan keterbacaannya.

\section{METODE PENELITIAN}

Penelitian ini merupakan penelitian kuantitatif yang dilakukan untuk menguji hipotesis yang telah ditetapkan. Sampel yang digunakan dalam penelitian ini diambil dari semua perusahaan yang terdaftar di Bursa Efek Indonesia periode 2018 yang menyediakan data yang dibutuhkan pada laporan tahunannya. Sampel akhir dalam penelitian ini berjumlah 482 observasi perusahaan.

Variabel dependen dalam penelitian ini adalah keterbacaan dari narasi pengungkapan laporan tahunan. Keterbacaan merupakan elemen yang berkaitan erat dengan teks (de Souza et al., 2019), sehingga pengukuran yang digunakan dalam penelitian ini adalah logaritma natural dari Jumlah Kata dari teks berdasarkan pada pengukuran yang telah dilakukan oleh peneliti terdahulu seperti de Souza et al. (2019), Li (2008), Asay et al. (2018), dan Xu et al. (2018). Jumlah kata yang semakin komplek dalam narasi pengungkapan akan membutuhkan usaha yang lebih optimal dari pembaca untuk memahami informasi yang sebenarnya (de Souza et al., 2019).

Adapun teks yang dimaksud dalam penelitian ini adalah Analisis dan Pembahasan Manajemen (selanjutnya disebut APM, dalam penelitian-penelitian terdahulu disebut Management Discussion \& Analysis). APM dipilih karena manajer harus mengungkapkan kinerja masa lalu dan prospek perusahaan di masa depan dalam APM (Li, 2008). Selain itu, pemilihan APM juga merujuk pada Keputusan Ketua Badan Pengawas Pasar Modal Nomor Kep38/PM/1996 yang menunjukkan kompleksitas item-item yang harus diungkapkan dalam APM.

Variabel Independen dalam penelitian ini adalah tenure CEO. Tenure CEO diukur dengan jumlah tahun masa jabatan CEO pada sebuah perusahaan. Selain itu, sebagai upaya untuk menekan bias hasil penelitian, peneliti menyertakan dua variable kontrol yaitu ukuran perusahaan yang diukur dengan logaritma natural dari total aset perusahaan, dan umur perusahaan yang diukur dengan jumlah tahun sejak pertama kali perusahaan didirikan.

Teknik analisis data yang digunakan dalam penelitian ini adalah teknik analisis regresi berganda. Adapun model penelitian dalam peneitian ini adalah sebagai berikut:

Read $=\propto+\beta_{1}$ Ten $-\beta_{2}$ Size $-\beta_{3}$ Age $+\varepsilon$

Keterangan:

Read = keterbacaan narasi pengungkapan dengan proxy jumlah kata APM

$\propto \quad=$ intersep

$\beta \quad=$ koefisien regresi variabel independen

Ten = tenure $\mathrm{CEO}$

Size = ukuran Perusahaan

Age = umur Perusahaan

$\varepsilon \quad=$ error 


\section{HASIL DAN PEMBAHASAN}

\subsection{Hasil Analisis Deskriptif Variabel}

Analisis deskriptif dilakukan untuk memberikan gambaran karakteristik data penelitian (Hitten, 2016). Berikut disajikan tabel analisis deskriptif dari data penelitian meliputi jumlah sampel, nilai rata-rata, nilai maksimum, nilai minimum, dan standar deviasi.

Tabel 1. Analisis Deskriptif Descriptive Statistics

\begin{tabular}{llrrrr}
\hline & N & Minimum & Maximum & Mean & Std. Deviation \\
\hline Ln Jumlah Kata & 490 & 2,225309281725 & 4,922247834731 & 3,574764385631 &, 3808162762706 \\
& & 863 & 226 & 577 & 98 \\
Tenure CEO & 606 & 1 & 54 & 7,14 & 8,543 \\
Ln Ukuran Perusahaan & 619 & 9,631517834157 & 15,74335918605 & 12,47836282337 &, 8584961540449 \\
& & 885 & 4980 & 9470 & 72 \\
Age & 625 & 1 & 117 & 31,31 & 17,046 \\
Valid N (listwise) & 482 & & & & \\
\hline
\end{tabular}

Berdasarkan Tabel 1 dapat diketahui bahwa sampel untuk keterbacaan yang di proxy kan dengan logaritma natural Jumlah Kata APM adalah 490, jumlah sampel untuk tenure CEO adalah 606, jumlah sampel untuk ukuran perusahaan adalah 619, dan jumlah sampel untuk umur perusahaan adalah 629. Selanjutnya data-data ini dipasangkan dengan bantuan alat statistik SPSS 25.0 sehingga sampel valid yang dapat diuji dalam penelitian ini adalah 482 sampel. Tabel 1 menunjukkan bahwa mean dari logaritma natural jumlah kata pada narasi APM adalah 3,57, mean untuk tenure CEO adalah 7,14, mean untuk ukuran perusahaan adalah 12,48, dan mean untuk umur perusahaan adalah 31,60. Selain itu, masing-masing nilai minimum dan maksimum dari logaritma natural jumlah kata adalah 2,23 dan 4,92, dari tenure CEO adalah 1 dan 54, dari ukuran perusahaan adalah 9,63 dan 15,74, dan dari umur perusahaan adalah 2 dan 117. Simpangan baku dalam data penelitian jumlah kata, tenure CEO, ukuran perusahaan, dan umur perusahaan masing-masing adalah $0.38,8.54,0.86$, dan 16.86 . Selain itu, pengujian asumsi klasik telah dilakukan dalam penelitian ini dan telah bebas dari semua uji asumsi klasik meliputi uji normalitas, uji multikolinieritas, uji heterokedastisitas, uji auto korelasi.

\subsection{Uji Korelasi}

Uji korelasi dalam penelitian ini dilakukan untuk mengetahui berapa besar variabel independen dapat menjelaskan variabel dependen dalam model penelitian. Tabel 2 menunjukkan nilai $\mathrm{R}$ Square adalah 0,362 yang berarti bahwa variabel independen dalam penelitian ini dapat menjelaskan variabel dependen sebesar 36,2\%, sedangkan sisanya dijelaskan oleh variabel lain dan error. Meski demikian, model penelitian yang ditetapkan dalam penelitian ini telah tepat karena berdasarkan uji FIT yang dilakukan untuk menguji ketepatan model diperoleh tingkat signifikansi sebesar 0,000 dan lebih kecil dari 0,05.

Tabel 2. Hasil Uji Korelasi

\begin{tabular}{lllll}
\hline \multicolumn{4}{c}{ Model Summaryb } \\
\hline Model & $\mathrm{R}$ & R Square & Adjusted $R$ Square & Std. Error of the Estimate \\
\hline 1 &, $601 \mathrm{a}$ &, 362 &, 358 &, 305125786383674 \\
a. Predictors: (Constant), Age, Tenure CEO, Ln Ukuran Perusahaan & \\
b. Dependent Variable: Ln Jumlah Kata & & \\
\hline
\end{tabular}


Tabel 3. Hasil Uji FIT

\begin{tabular}{|c|c|c|c|c|c|c|}
\hline \multicolumn{7}{|c|}{ ANOVAa } \\
\hline Model & & Sum of Squares & df & Mean Square & $\mathrm{F}$ & Sig. \\
\hline \multirow[t]{3}{*}{1} & Regression & 25,201 & 3 & 8,400 & 90,227 & ,000b \\
\hline & Residual & 44,503 & 478 & ,093 & & \\
\hline & Total & 69,703 & 481 & & & \\
\hline \multicolumn{7}{|c|}{ a. Dependent Variable: Ln Jumlah Kata } \\
\hline
\end{tabular}

\subsection{Uji Koefisien Regresi}

Berdasarkan Tabel 4 dapat diketahui model regresi dalam penelitian ini adalah sebagai berikut:

$\operatorname{Read}=2,768+2,426_{\text {Ten }}-14,238_{\text {Size }}-2,948_{\text {Age }}+\varepsilon$

Tabel 4. Hasil Uji Koefisien Regresi

\begin{tabular}{|c|c|c|c|c|c|c|}
\hline \multicolumn{7}{|c|}{ Coefficients $^{\mathrm{a}}$} \\
\hline Model & & $\begin{array}{c}\text { Unstandardized } \\
\mathrm{B}\end{array}$ & $\begin{array}{l}\text { Coefficients } \\
\text { Std. Error }\end{array}$ & $\begin{array}{c}\text { Standardized } \\
\text { Coefficients Beta }\end{array}$ & $\mathrm{t}$ & Sig. \\
\hline 1 & (Constant) & ,564 & ,204 & & 2,768 & ,006 \\
\hline & Tenure CEO & ,004 & ,002 & ,089 & 2,426 & ,016 \\
\hline & Ln Ukuran Perusahaan &,- 238 &,- 017 &,- 547 & $-14,238$ & ,000 \\
\hline & Age &,- 003 &,- 001 &,- 114 & $-2,948$ & 003 \\
\hline
\end{tabular}

Model ini menunjukkan bahwa bertambahnya tenure CEO selama 1 tahun akan meningkatkan keterbacaan 2,426 dengan asumsi variabel lain dalam model penelitian adalah konstan. Bertambahnya kompleksitas kata dalam penilitian ini menunjukkan berkurangnya tingkat keterbacaan. Tabel 4 juga menunjukkan bahwa tenure CEO berpengaruh positif terhadap keterbacaan pada tingkat siginifikansi 5\%, sedangkan ukuran perusahaan dan umur perusahaan berpengaruh negatif terhadap keterbacaan pada tingkat signifikansi $1 \%$. Hal ini dapat dilihat dari nilai sig yang diperoleh pada uji koefisien regresi untuk variabel tenure CEO, ukuran perusahaan, dan umur perusahaan masing-masing sebesar 0.016, 0.000, dan 0.003 .

\subsection{Pembahasan}

Variabel utama dalam penelitian ini adalah tenure CEO dan keterbacaan yang diukur dengan jumlah kata. Berdasarkan Tabel 4 diketahui bahwa koefisen tenure CEO adalah positif $(2,426)$ dan signifikan pada tingkat signifikasi 5\% (sig 0,016 < 0,05), sehingga dapat disimpulkan bahwa H1 dikonfirmasi. Hal ini menunjukkan bahwa tenure CEO berpengaruh positif siginfikan pada keterbacaan narasi yang dibuatnya. CEO yang memiliki tenure yang panjang mampu untuk membuat narasi yang lebih sederhana dan lebih mudah untuk dibaca karena CEO lebih memahami bagaimana cara mengkomunikasikan kondisi perusahaan dengan jelas.

Katmon et al. (2017) menjelaskan bahwa bertambahnya tenure CEO akan seiring dengan meningkatnya pemahaman CEO pada kondisi perusahaan, peraturan, dan regulasi sehingga tenure CEO akan meningkatkan kualitas pengungkapan (Donoher et al., 2007), dimana kualitas pengungkapan akan meningkat seiring dengan meningkatnya tingkat keterbacaan (Luo et al., 2018). Penjelasan ini menunjukkan bahwa tenure CEO dapat mengatasi masalah keterbacaan dengan penjelasan ontologis bahwa CEO dengan tenure yang lama lebih mampu untuk 
mengkomunikasikan kondisi perusahaan yang komplek dengan bahasa yang lebih sederhana dan mudah dibaca dari pada CEO dengan tenure yang lebih pendek.

Selain itu, Streers dan Porter (1983) menyatakan bahwa bertambahnya masa jabatan CEO akan menciptakan rasa memiliki dan loyalitas yang semakin besar kepada perusahaan. Pada akhirnya, CEO akan memberikan kinerja terbaik demi perusahaan dan akan mencegahnya dari perbuatan-perbuatan oportunistik yang akan merugikan perusahaan. Penjelasan ini menunjukkan bahwa tenure CEO dapat mengatasi masalah keterbacaan dengan penjelasan oportunistik. CEO dengan tenure yang lama akan cenderung lebih loyal kepada perusahaan dan mengurangi sifat oportunistiknya. CEO akan mengungkapkan informasi dengan lebih jelas dan lebih mudah untuk dibaca sebagai upaya menghindari obfuscation hypothesis atau upaya membingungkan pembaca demi keuntungan pribadi CEO dan merugikan perusahaan.

Hasil temuan ini juga selaras dengan teori upper echelons yang menyatakan bahwa karakteristik pimpinan perusahaan seperti tenure dapat mempengaruhi strategi, arah, dan operasi perusahaan (Hambrick dan Mason, 1984). Tenure yang dimiliki oleh CEO akan menggambarkan bagaimana upaya $\mathrm{CEO}$ untuk menciptakan tingkat keterbacaan dari narasi pengungkapan yang akan memberikan konsekuensi tersendiri bagi perusahaan. Tingkat keterbacaan yang tinggi tentu akan memberikan efek positif bagi perusahaan, sedangkan tingkat keterbacaan yang rendah akan memberikan efek negatif bagi perusahaan (de Souza et al., 2019; Li, 2008; Luo et al., 2018; Rennekamp, 2012; Wisniewski dan Yekini, 2015).

Variabel kontrol dalam penelitian ini adalah ukuran perusahaaan dan umur perusahaan. Berdasarkan Tabel 7 diketahui bahwa koefisen dari ukuran perusahaan adalah negatif $(-14,238)$ dan siginifikan pada tingkat $1 \%$ ( $\operatorname{sig} 0,000<0,001$ ), sehingga dapat disimpulkan bahwa ukuran perusahaan yang semakin besar akan menyebabkan bertambahnya kompleksitas dari narasi pengungkapan dan menurunkan tingkat keterbacaannya. Hasil ini selaras dengan argumen bahwa perusahaan yang semakin besar akan menyebabkan kompleksitas operasi yang tinggi dan menyebabkan banyaknya hal yang harus disampaikan dalam narasi pengungkapan (Heniwati dan Yani, 2011; Li, 2008).

Adapun variabel kontrol umur perusahaan dalam penelitian ini juga berpengaruh negatif dengan koefisien yang dihasilkan sebesar -2,948, dan siginifikan pada tingkat 5\% karena nilai sig yang dihasilkan adalah $0,003<0,005$. Hasil ini menunjukkan bahwa umur perusahaan yang semakin tua akan menciptakan kompleksitas operasi yang semakin luas, jumlah relasi yang semakin banyak, dan aset yang semakin besar, sehingga banyak item yang harus diungkapkan dan meningkatkan kompleksitas narasi pengungkapan yang pada akhirnya berpengaruh pada menurunnya keterbacaan.

\section{SIMPULAN DAN REKOMENDASI}

Penelitian ini menyimpulkan bahwa tenure CEO berpengaruh positif dan signifikan terhadap keterbacaan narasi pengungkapan, yang berarti bahwa semakin panjang tenure CEO maka semakin meningkatkan keterbacaan narasi pengungkapan. Tenure CEO yang panjang dapat meningkatkan pengalaman dan pemahaman CEO terhadap kondisi perusahaan termasuk cara berkomunikasi dengan pihak-pihak yang berkepentingan dengan perusahaan. Selain itu, bertambahnya tenure CEO dapat menumbuhkan loyalitas yang semakin kuat pada perusahaan, sehingga CEO akan memberikan kinerja terbaik dan menekan sifat oportunistik seperti dengan 
sengaja meningkatkan kompleksitas narasi pengungkapan (menurunkan keterbacaan) sebagai upaya membingungkan pembaca demi kepentingan pribadi CEO.

Ukuran perusahaan dan umur perusahaan berpengaruh negatif dan siginifikan terhadap keterbacaan, yang berarti semakin besar dan semakin tua perusahaan maka akan semakin kompleks narasi pengungkapan yang dihasilkan dan menurunkan keterbacaan narasi pengungkapan. Hal ini menunjukkan bahwa bertambahnya aset dan umur perusahaan akan seiring dengan bertambahnya kompleksitas operasi perusahaan dan pada akhirnya menuntut perusahaan untuk menyampaikan lebih banyak narasi dalam pengungkapan yang dibuat.

Penelitian ini berkontribusi untuk memperkaya literatur tentang pengaruh karakteristik CEO khususnya tenure CEO terhadap keterbacaan narasi pengungkapan. Hasil penelitian ini dapat menjadi salah satu rujukan bagi pihak yang berkepentingan untuk mengevaluasi CEO dengan mempertimbangkan aspek karakteristik dari CEO itu sendiri sesuai dengan teori upper echelons yang dikembangkan oleh Hambrick dan Mason (1984). Sejauh sepengetahuan penulis, penelitian tentang keterbacaan narasi pengungkapan di Indonesia masih belum banyak disentuh oleh akademisi, padahal keterbacaan narasi pengungkapan merupakan hal yang penting karena berkaitan dengan bagaimana informasi dalam pengungkapan dapat dipahami oleh pengguna. Penelitian ini diharapkan dapat memotivasi para akademisi untuk mengembangkan penelitianpenelitian tentang keterbacaan narasi pengungkapan di Indonesia.

\section{DAFTAR PUSTAKA}

Asay, H. S., Libby, R., \& Rennekamp, K. (2018). Firm performance, reporting goals, and language choices in narrative disclosures. Journal of Accounting and Economics, 65(23), 380-398. https://doi.org/10.1016/j.jacceco.2018.02.002.

Bonsall IV, S. B., Leone, A. J., Miller, B. P., \& Rennekamp, K. (2017). A plain English measure of financial reporting readability. Journal of Accounting and Economics, 63(2-3), 329357. https://doi.org/10.1016/j.jacceco.2017.03.002.

de Souza, J. A. S., Rissatti, J. C., Rover, S., \& Borba, J. A. (2019). The linguistic complexities of narrative accounting disclosure on financial statements: An analysis based on readability characteristics. Research in International Business and Finance, 48, 59-74. https://doi.org/10.1016/j.ribaf.2018.12.008

Donoher, W. J., Reed, R., \& Storrud-Barnes, S. F. (2007). Incentive alignment, control, and the issue of misleading financial disclosures. Journal of Management, 33(4), 547-569. https://doi.org/10.1177/0149206307302550.

Ginesti, G., Drago, C., Macchioni, R., \& Sannino, G. (2018). Female board participation and annual report readability in firms with boardroom connections. Gender in Management: An International Journal, 33(4), 296-314. https://doi.org/10.1108/GM-07-2017-0079.

Guthrie, J., Petty, R., Yongvanich, K., \& Ricceri, F. (2004). Using content analysis as a research method to inquire into intellectual capital reporting. Journal of intellectual capital, 5(2), 282-293. https://doi.org/10.1108/14691930410533704.

Hambrick, D. C. (2007). Upper echelons theory: An update: Academy of Management Briarcliff Manor, NY 10510. https://journals.aom.org/doi/abs/10.5465/amr.2007.24345254.

Hambrick, D. C., \& Mason, P. A. (1984). Upper echelons: The organization as a reflection of its top managers. Academy of management review, 9(2), 193-206. https://journals.aom.org/doi/abs/10.5465/AMR.1984.4277628. 
Hasan, M. M. (2018). Readability of narrative disclosures in 10-K reports: Does managerial ability matter? European Accounting Review, 1-22. https://doi.org/10.1080/09638180.2018.1528169.

Hassan, M. K., Abu Abbas, B., \& Garas, S. N. (2019). Readability, governance and performance: a test of the obfuscation hypothesis in Qatari listed firms. Corporate Governance: The International Journal of Business in Society, 19(2), 270-298. https://doi.org/10.1108/CG05-2018-0182.

Heniwati, E., \& Yani, E. (2011). Pengaruh Karakteristik Perusahaan Terhadap Kelengkapan Pengungkapan Pada Laporan Keuangan Tahunan Perusahaan Properti Dan Real Estate. Jurnal Ekonomi Bisnis dan Kewirausahaan (JEBIK), 2(1). http://dx.doi.org/10.26418/jebik.v2i1.700.

Hitten, A. (2016). Kebijakan Dividen dari Perspektive Agency Cost Model (Studi Kasus Perusahaan yang Terdaftar di Bursa Efek Indonesia periode 2011-2013). Jurnal Ekonomi Bisnis dan Kewirausahaan (JEBIK), 5(1), 73-93. http://dx.doi.org/10.26418/jebik.v5i1.16184.

Katmon, N., Mohamad, Z. Z., Norwani, N. M., \& Al Farooque, O. (2017). Comprehensive board diversity and quality of corporate social responsibility disclosure: evidence from an emerging market. Journal of Business Ethics, 1-35. https://doi.org/10.1007/s10551-0173672-6.

Kuppens, B. J. G. M. (2012). The Role of CEO-CFO Interactions in Relation to Financial Policy and Performance. Tilburg University.

Leung, S., Parker, L., \& Courtis, J. (2015). Impression management through minimal narrative disclosure in annual reports. The British accounting review, 47(3), 275-289. https://doi.org/10.1016/j.bar.2015.04.002.

Li, F. (2008). Annual report readability, current earnings, and earnings persistence. Journal of $\begin{array}{llll}\text { Accounting and 221-247. } & \text { Economics, }\end{array}$ https://doi.org/10.1016/j.jacceco.2008.02.003.

Lo, K., Ramos, F., \& Rogo, R. (2017). Earnings management and annual report readability. Journal of Accounting and Economics, 63(1), 1-25. https://doi.org/10.1016/j.jacceco.2016.09.002.

Loughran, T., \& McDonald, B. (2014). Measuring readability in financial disclosures. The Journal of Finance, 69(4), 1643-1671. https://doi.org/10.1111/jofi.12162.

Luo, J.-h., Li, X., \& Chen, H. (2018). Annual report readability and corporate agency costs. China journal of accounting research, 11(3), 187-212. https://doi.org/10.1016/j.cjar.2018.04.001.

Mai, F., Tian, S., Lee, C., \& Ma, L. (2019). Deep learning models for bankruptcy prediction using textual disclosures. European Journal of Operational Research, 274(2), 743-758. https://doi.org/10.1016/j.ejor.2018.10.024.

Morsing, M., \& Schultz, M. (2006). Corporate social responsibility communication: stakeholder information, response and involvement strategies. Business ethics: a European review, 15(4), 323-338. https://doi.org/10.1111/j.1467-8608.2006.00460.x.

Rennekamp, K. (2012). Processing fluency and investors' reactions to disclosure readability. Journal of Accounting Research, 50(5), 1319-1354. https://doi.org/10.1111/j.1475679X.2012.00460.x. 
Smith, M., Jamil, A., Chik Johari, Y., \& Ahmar Ahmad, S. (2006). The chairman's statement in Malaysian companies: A test of the obfuscation hypothesis. Asian Review of Accounting, 14(1/2), 49-65. https://doi.org/10.1108/13217340610729464.

Streers, R. M., \& Porter, L. W. (1983). Motivation and work behavior. NY: McGraw-Hill. Mook, DG,(1987). Motiveation, The Organization of Action, NY: WW Norton.

Wei, J., Ouyang, Z., \& Chen, H. A. (2018). CEO characteristics and corporate philanthropic giving in an emerging market: The case of China. Journal of Business Research, 87, 111. https://doi.org/10.1016/j.jbusres.2018.02.018.

Wisniewski, T. P., \& Yekini, L. S. (2015). Stock market returns and the content of annual report narratives. Paper presented at the Accounting Forum. https://doi.org/10.1016/j.accfor.2015.09.001.

Wolk, H. I., Dodd, J. L., \& Rozycki, J. J. (2013). Accounting Theory Conceptual Issues in a Political and Economic Environment eighth edition. United States of America: SAGE Publication, Inc.

Xu, Q., Fernando, G. D., \& Tam, K. (2018). Executive age and the readability of financial reports. Advances in accounting, 43, 70-81. https://doi.org/10.1016/j.adiac.2018.09.004. 